\title{
РЕЧЕВОЙ АКТ СОГЛАСИЯ И СПОСОБЫ ЕГО ВЫРАЖЕНИЯ В РУССКОМ ЯЗЫКЕ
}

\section{SPEECH ACT OF CONSENT AND WAYS OF EXPRESSING IT IN RUSSIAN LANGUAGE}

Gholamy Hossein Vafai Azadeh

Summary: The article presents the results of a study of ways to implement the category of consent on the material of the Russian language. The linguistic essence of the concept of consent, the functioning of consent as a line of behavior in discourse, as well as the features of the speech act of consent are analyzed. The study of the speech act of consent is carried out in the field of pragmatics, one of the areas of linguistics that studies the relationship of linguistic units and the behavior of signs in real communication processes. The work analyzes different types of speech acts. Further, it is proved that the speech act of consent is considered a representative speech act. As factual material, examples from Russian fiction and colloquial speech are used to determine the functionally directed categorization by phrasemes. Situations of consent neutralization, caused either by the complexity of the discursive conditions, or by the speaker's personal qualities, are also described. Analysis of different examples in contexts shows that there are different ways to implement the speech act of consent in the Russian language.

Keywords: pragmalinguistics, consent, speech act, communicative category, Russian language.

\author{
Голами Хосейн \\ К.филол.н., профессор, Тегеранский университет, \\ Иран, Тегеран, Амирабад \\ hgholamy@ut.ac.ir \\ Baфаu Азаде \\ Аспирант, Тегеранский университет, \\ Иран, Тегеран, Амирабад \\ vafai.azadeh@yahoo.com
}

Аннотация: В статье изложены результаты исследования способов реализации категории согласия на материале русского языка. Анализируется лингвистическая сущность понятия согласия, функционирование согласия как линии поведения в дискурсе, а также особенности речевого акта согласия. Исследование речевого акта согласия проводится в области прагматики, одной из областей лингвистики, изучающей отношение языковых единиц и поведение знаков в реальных процессах коммуникации. В работе анализируются разные типы речевых актов. Доказывается, что речевой акт согласия считается репрезентативным речевым актом. В качестве фактического материала привлекаются примеры из русской художественной литературы и разговорной речи для определения функционально направленной категоризации фразем. Описываются также ситуации нейтрализации согласия, обусловленные либо сложностью дискурсивных условий, либо личностными качествами говорящего. Анализ разных примеров в контекстах, показывает, что существуют разные способы реализация речевого акта согласия в русском языке.

Ключевые слова: прагмалингвистика, согласие, речевой акт, коммуникативная категория, русский язык.

По мнению Остина все глаголы разделяются на две группы: констативные и перформативные. Констативные глаголы сами по себе не совершают акта, но перформативные глаголы совершают акт. В следствии этой классификации глаголов возникла теория речевого акта. У каждого человеческого акта есть намерение и цель. Речевой акт имеет особенную структуру:

Локуция - произнесение звуков;

Иллокуция - намерение говорящего;

Перлокуция - результат акта.

Существуют разные классификации речевого акта. Основная из них - классификация Серля.

Серль выделяет 5 основных типов речевых актов. Он предлагает следующие речевые акты: репрезентативные, директивные, экспрессивные, декларативные, коммисивные.

Цель репрезентативов - сообщение о положении, действии. 
Цель директивов - побудить собеседника выполнить какое-то действие.

Цель экспрессивов - выразить психологическое состояние.

Цель декларативов - внесение изменений полномочным лицом в статус указыаемого объекта.

Цель коммисивов - возложить обязательство выполнить некоторое действие.

В диалогической речи возникновение реакции согласия инициируется предшествующим высказыванием адресанта (A1), который использует различные языковые средства с целью речевого воздействия на адресата (А2). Коммуникативная цель А2 состоит в том, чтобы выразить свою сходную точку зрения по отношению к предыдущему высказыванию А1. Таким образом, речевой акт согласия представляет собой реагирующий $\mathrm{PA}$, который выражает положительную реакцию адресата на предшествующий РА, что находит в речи определенное языковое воплощение. [2, с. 201]

Работы многих авторов посвящены вопросам репрезентации согласия (Ш.А. Ахадов, М.В. Баделина, М.Е. Баскова, И.В. Галактионова, Н.Н. Гастева, Е.Р. Добрушина, В.В. Казаковская, В.И. Красных, П.А. Лекант, Е.А. Михайлова, О.Н. Морозова, О.В. Озаровский, Н.И. Поройкова, Т.М. Свиридова, А.Г. Хорошавина и др.). К числу мало изученных относится проблема системного описания средств выражения согласия в аспекте коммуникативнопрагматической парадигмы.

По данным «Словаря русского языка» С.И. Ожегова, согласие имеет следующие значения:

1. Одно из течений внутри старообрядческого толка

2. Разрешение, утвердительный ответ на просьбу. Согласия начальника (получение его согласие). Молчание -знак согласия

3. Единомыслие, общность точек зрения. Прийти к согласию. Гражданское согласие (отсутствие конфронтации в обществе).

4. Дружественные отношения, единодушие. В семье царит полное согласие

5. Соразмерность, стройность, гармония. В оркестре нет согласия.

Вокруг имени существительного «согласие», группируются связанные с ним лексические средства, которые отличаются высокой степенью активности. Разные по семантике глаголы приобретают особую актуальность, позволяют обнаружить специфические и универсальные признаки согласия. Информационная характеристика согласия связана с внутренней синтагматикой глагольно-именных сочетаний, с валентными свойствами имен- ного компонента. Семантическая особенность глаголов заключается в назывании действий, представляющих своеобразный аспект картины согласия: высказать/выразить/подтвердить и т.п. согласие; дать согласие; достичь! добиться! получить! вырабатывать! искать/просить/требовать и др. + 'согласие'; жить/находиться в согласии; надеяться на согласие; обсудить/оценить согласие; желать согласия; уклониться от согласия и мн. др. Семантическая структура глаголов обозначает параметры действий, включает значение интенсивности, оценочности.[3, с. 175]

Речевой акт согласия является реакцией на такие речевые акты как репрезентативные, директивные, коммисивные и экспрессивные.

Репрезентативные речевые акты сообщают о положении или действия. К таким речевым актам относятся сообщения, утверждения, описания, констатации и т.д.

Директивные речевые акты побуждают собеседника выполнить какое-то действие. Внутри данного класса выделяются кооперативные (просьба, совет, предложение, приглашение) и некооперативные (приказ, команда, инструкция, распоряжение). Речевой акт согласия на директивы - это речевой акт со значением волеизъявления, т.е. согласие адресата выполнить некое действие, к совершению которого его побуждает адресант.

Коммисивные речевые акты возлагают обязанность выполнить некоторое действие. Эпизоды общения, в которых согласие инициируется комиссивными речевыми актами, могут развиваться следующим образом. Адресант принимает на себя обязательства совершить некое действие, либо следовать определенной линии поведения и информирует адресата о своем намерении. Реакция согласия возникает при наличии у А2 заинтересованности или потребности в исполнении действия А1. Кроме того, адресат может оценить предполагаемое действие с точки зрения его обязательности, целесообразности, уместности.

Экспрессивные речевые акты выражают психологические состояния. К составу класса экспрессивов относятся такие речевые действия как благодарность, извинение, комплимент, приветствие и прощание, соболезнование, выражение радости или гнева и многие другие. Большинство из них занимают важное место в системе ритуальных актов речевого этикета, которые предполагают стандартные формы поведения при взаимодействии коммуникантов в определенных ситуациях. То есть, существуют типизированные ситуации с фиксированной последовательностью речевых действий участников общения. Помимо этого, в процессе речевого взаимодействия возникают ситуации, в которых функционирование экспрессивных речевых действий и 
реакций на них отличаются от шаблонных, стандартных образцов ритуального пространства. Такие ситуации особенно интересны в плане реализации РА согласия как ответной реакции на некоторые типы экспрессивных речевых актов.[2, с. 205]

Здесь возникает такой вопрос: к какому из типов речевых актов относится РА согласия? Речевой аки согласие относится к репрезентативам. Это следует уже из самого определения этого типа: "Смысл, или цель, члена класса репрезентативов - в том, чтобы зафиксировать (в различной степени) ответственность говорящего за сообщение о некотором положении дел, за истинность выражаемого суждения. Все элементы класса репрезентативов могут оцениваться по шкале, включающей истину и ложь... Направление приспособления здесь - "слова реальность", выражаемое психологическое состояние 'убеждение, (что р)". Серль выделяет репрезентативы на основе 4 признаков, предложенных им для классификации.

Первый признак репрезентативов: цель состоит в фиксации ответственности говорящего за истинность выражаемого суждения. Каждое высказывание РА согласия может быть обсуждено с точки зрения истинности его пропозитивного содержания. Этим, в частности, объясняется возможность выражать согласие с репликой, которая в свою очередь является выражением согласия.

Второй признак репрезентативов - направление приспособления определяется Дж. Серлем как "слова реальность", т.е. слова приспосабливаются к миру, они должны этот мир адекватно описывать (ср. противоположное направление "реальность - слова" когда слова стремятся изменить мир). Ясно, что и по этому признаку речевой акт согласия относится к репрезентативам.

Третий признак: психологическое состояние - убеждение. В РА согласия не выражается какого-либо желания, потребности, намерения и т.д. что свойственно другим типам РАктов.

И, наконец, четвертый признак репрезентативов: пропозициональное содержание - некоторая верифицируемая пропозиция (а не будущее действие Г или С, например). По этому признаку Ракт согласия также относится к репрезентативам.[5, с. 263]

Способы выражения согласий:

- «Да»

Самой употребительной формой выражения согласия в русском языке является слово-предложение «да».

- Наполеон велик, потому что он стал выше революции, подавил ее злоупотребления, удержав все хорошее - и равенство граждан, и свободу слова и печати, - и только потому приобрел власть.

- Да, ежели бы он, взяв власть, не пользуясь ею для убийства, отдал бы ее законному королю, - сказал виконт, - тогда бы я назвал его великим человеком.[6, с. 132]

Коммуникатив «да» не всегда может выражать согласие, например:

- Разве можно это сравнивать?.. - сказал Пьер. Князь Андрей перебил его. Он резко закричал:

- Да, опять просить ее руки, быть великодушным и тому подобное?.. Да, это очень благородно, но я не способен идти sur les brisées de monsieur. (Толстой, 1996)

- «Пожалуйста», также его употребление с частицей «да»: «Да, пожалуйста»

- Словапредложения, которые выражаются, в основном, модальными словами: верно, правильно, хорошо, ладно, еще бы, охотно; Также употребление некоторых из них с частицей «да»: «Да, конечно»;

- - указание времени: «Одну минуточку», «Момент», «Секундочку», «Сию минуту», «Сейчас-сейчас». Часто употребляется с уменьшительно-ласкательным суффиксом, методом повтора; - различные междометия: «ага», «угу». Также частицы: «вот»; предлог: «на»; выражения типа: «да-да», «о да!». (Владимировна, 2012)

- Повтор используется очень часто; - слова с оттенком точной уверенности: «разумеется», «естественно», «обязательно», «безусловно»;

- Выражение согласия с побудительным наклонением.

- Немного овса прикажете?

- Иди, иди скорее, - подтвердил старик. [6, с.349]

- Выражение радости и удовольствия при выполнении действия: «С удовольствием», «С радостью», «Всегда рада помочь», «Буду рада помочь»;

- Заимствования: «Ок», «Гуm», «One moment, please», «Why not?»;

- - - Глаголы первого лица будущего времени:

- По крайней мере, вы можете взять назад свои слоBa. A?

- Беру, беру назад. [6, с.178]

- Ответы вопросом на вопрос, но с оттенком положительного ответа: «Что-нибудь ещё?»;

- Выражение нетрудности адресата при выполнении действия: «Без проблем», «Легко», «Запросто», «Без вопросов», «Никаких проблем», «С лёгкостью»;

- Глаголы в сослагательном наклонении единственного числа: «Мог бы»;

- Устойчивые выражения: «Считайте, что уже сделано», «Сказано - сделано ", «О чём речь!»; - важную роль для адресата играет тот, кто его просит: «Только по- 
тому, что хорошо к тебе отношусь», «Приму за честь», «Для тебя - всё, что угодно», «Для Вас - всегда пожалуйста»; [5, с.264]

\section{- Bопрос, на который ответ не требуется.}

- Так прикажете стерлядей больших взять? - спросил эконом.

- Что ж делать, возьми, коли не уступают. [6, с.98]

- Пословицы и поговорки дают возможность представить и описать существенные фрагменты кон- цептуальной системы согласия: Согласие крепче каменных стен; В согласном стаде волк не страшен; Положить ружье (согласиться); Молчание - знак согласия и др. $[3$, c.65]

- Невербальные средства: кивок головой; улыбка; рукопожатие.

- Сочетания предыдущих способов в различных комбинациях: «Могу, конечно», «Разумеется, для Вас всегда пожалуйста» и т.д

\section{ЛИТЕРАТУРА}

1. Радбиль, Т. Возможности и перспективы применения теории речевых актов в лингвистической экспертизе. Вестник нижегородского университета им. Любачевского.2013. № 1. с.286-290

2. Архипова, Е. Особенности функционирования речевого акта согласия/несогласия в различных типах эпизодов. Вопросы психолингвистики. 2012 . № 16. C. 198-207

3. Свиридова, Т. Категория согласия/несогласия в русском языке. дис.канд.фил. наук: 10.02,01: защищена в. 2008. Елец: Елецкий государственный университет'.223С Елец

4. Галактионова, И. Средства выражения соглашения/несоглашения в русском языку. дис.канд.фил. наук: 10.02,01: защищена в. 1995.Москва: Московский государственный университет им. М.В.Ломоносова.263С

5. Владимировна, Р. Способы выражения согласия/несогласия в русском языке на примере коммуникативного акта просьбы. Молодой ученый №3, 262-265.

6. Толстой, Л.Н. Война и мир. Собрание сочинений в 8 т. [Текст] / Л.Н. Толстой. - М.: Русский вестник, 1867. - С. 16-460.

с Голами Хосейн (hgholamy@ut.ac.ir), Вафаи Азаде (vafai.azadeh@yahoo.com).

Журнал «Современная наука: актуальные проблемы теории и практики»

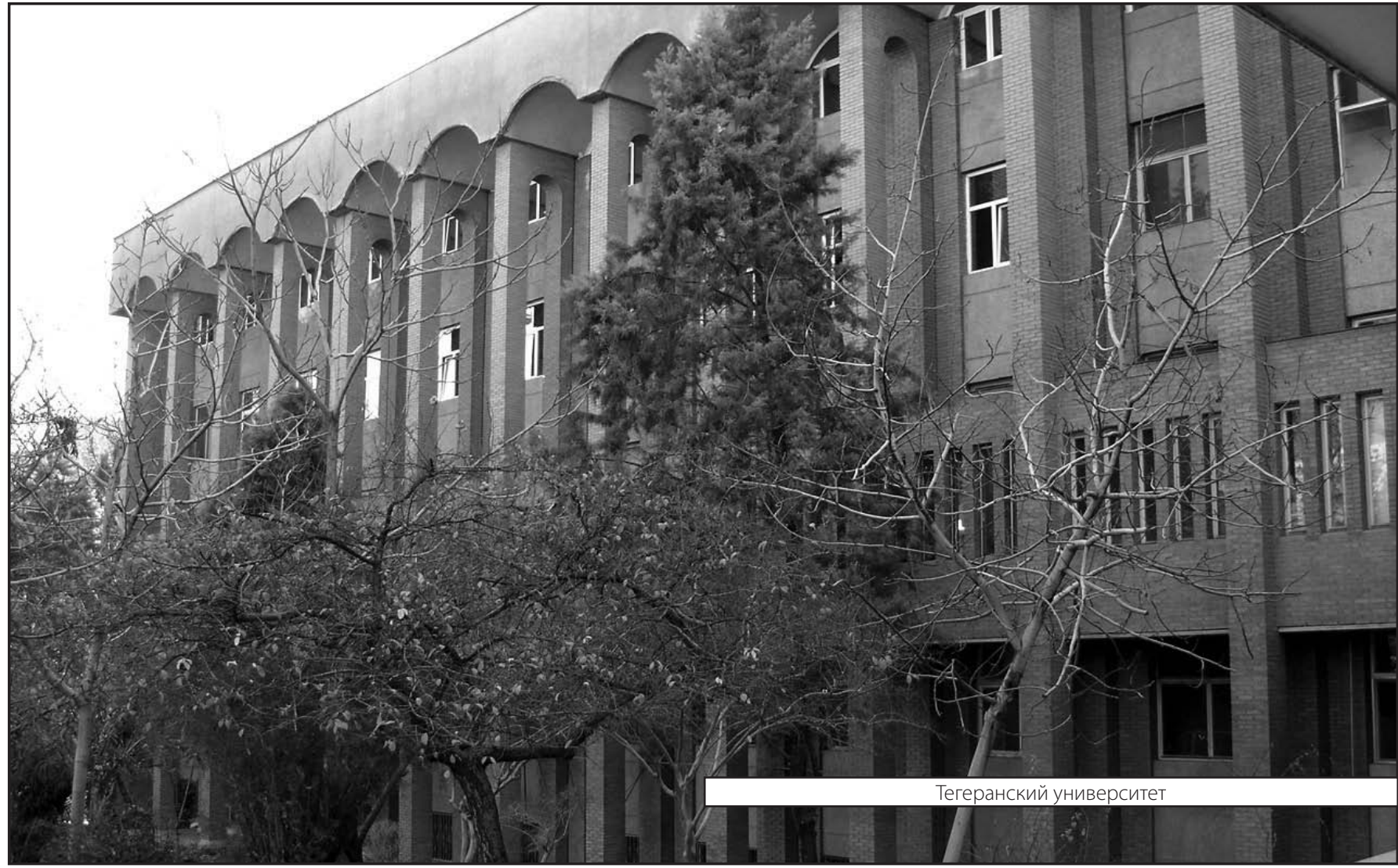

